\title{
Age dependent mate choice influences reproductive and progeny attributes in aphidophagous ladybird beetles (Coleoptera: Coccinellidae)
}

\author{
MAHADEV BISTA and OMKAR* \\ Ladybird Research Laboratory, Department of Zoology, University of Lucknow, 226007 Lucknow, India; \\ e-mails: omkaar55@hotmail.com; bistamahadev@yahoo.com
}

Key words. Coleoptera, Coccinellidae, Coccinella septempunctata, Coccinella transversalis, mate choice, ladybirds, mating behaviour, reproductive attributes, progeny fitness

\begin{abstract}
Despite the many studies on age based mate choice in insects, the question of how age influences mate choice in predaceous ladybird beetles is still unexplored. The present study evaluates age based mate choice in two sympatric aphidophagous ladybirds, Coccinella septempunctata L. and Coccinella transversalis Fab., in terms of mating behaviour (latent period, number of bouts, bout interval and duration of wriggling movements and mating), fecundity, egg viability and the development and survival of their progeny. Results revealed that middle aged (30-40 days) mates were preferred by young (10-15 days post-eclosion), middle aged (30-40 days) and old ( $45-55$ days) individuals of both sexes. Mating behaviour and egg viability differed significantly with male age whereas fecundity, offspring development and survival differed significantly with female age. The shortest latent periods and bout intervals, highest numbers of bouts, longest durations of wriggling movements and mating, and maximum egg viability were recorded for middle aged males whereas fecundity, percentage pupation and adult emergence of offspring were highest and durations of immature development were shortest for middle aged females. Thus, the present study indicates that middle aged individuals of $C$. septempunctata and $C$. transversalis are most preferred as mates as they have the highest reproductive output and produce the fittest offspring.
\end{abstract}

\section{INTRODUCTION}

Mate choice, or intersexual selection (Andersson, 1994; Andersson \& Simmons, 2006), which has evolutionary consequences (Jennions \& Petrie, 1997; Rodriguez \& Greenfield, 2003), has been investigated in numerous species, including insects (Birkinshaw \& Smith, 2001; McNamara et al., 2004; Srivastava \& Omkar, 2005; Fedina \& Lewis, 2008; Watson \& Simmons, 2010; Pandey \& Omkar, 2013; Mishra \& Omkar, 2014). Although, mate choice is costly in terms of the energy and time expended in searching and assessing mates (Johnstone et al., 1996; Watson et al., 1998), risk of rejecting good mates (Real, 1990), risk of predation (Rowe, 1994) and injury (Bonduriansky \& Brooks, 1998), it is still exhibited by both sexes.

Male mate choice is rarer than female mate choice, and occurs when males: (i) transfer substantial quantities of nutrients during copulation, (ii) are involved in parental care, and (ii) the females vary greatly in quality (Jennions \& Petrie, 1997; Bonduriansky, 2001). On the other hand, female mate choice is very common. It is believed that females benefit from certain male traits (Holland \& Rice, 1998; Gavrilets et al., 2001), which leads to the co-evolution of certain preferred male traits and female mate preference (Kirkpatrick \& Ryan, 1991; Jennions \& Petrie, 2000).

Among the various extrinsic (e.g. risk of predation, ambient light, seasonal changes; Gamble et al., 2003; Borg et al., 2006) and intrinsic (e.g. body size, experience, age; Mautz \& Sakaluk, 2008) factors that influence mate choice in insects, age is thought to play a crucial role. Previous studies indicate a significant influence of age based mate choice in insects and its effect on reproduction of the parental generation, and development and survival of their offspring (Fox et al., 2003; Moore \& Harris, 2003; Avent et al., 2008; Perez-Staples et al., 2010; Prathibha et al., 2011; Pandey \& Omkar, 2013).

Despite the many studies on many insect species, age based mate choice has not been studied in ladybird beetles (Coleoptera: Coccinellidae), the commonest insect predators of agricultural pests. Although, many attempts have been made in the past to decipher age-specific mating incidences in ladybirds and their effects on reproduction and fitness of their progeny (Arnqvist \& Nilsson, 2000; Srivastava \& Omkar, 2004; Omkar \& Pervez, 2005; Omkar et al., 2010; Omkar \& Singh, 2010), the question of how mate age influences mate choice and mating behaviour in ladybirds is still unanswered. The present study explores the effects of age on mate choice, mating behaviour, reproduction and offspring development and survival in two aphidophagous ladybirds, Coccinella septempunctata L. and Coccinella transversalis Fab.

Coccinella septempunctata is of Palearctic origin and is now ubiquitous owing to its euryphagous nature, and ecological plasticity in terms of both genetic and phenotypic polymorphisms (Omkar \& Pervez, 2002; Hodek \& Michaud, 2008); while C. transversalis is another large aphidophagous ladybird of Oriental region, native to India and found mainly in South Asia (Omkar \& Bind, 1993). Since, $C$. septempunctata and $C$. transversalis are the most effective ladybird biocontrol agents in agricultural crops in

\footnotetext{
* Corresponding author.
} 
India (Kumar et al., 2014), they were chosen for the present study.

As the studies on age-specific mating incidences in ladybirds (see Srivastava \& Omkar, 2004; Omkar \& Pervez, 2005; Omkar et al., 2010; Omkar \& Singh, 2010) indicate that middleaged mates have the highest fecundity and egg viability, and their offspring develop fastest; we hypothesized that: (i) under choice-test conditions, middle aged males/females would prefer middle aged partners rather than young and old partners, and (ii) middle aged partners would be more likely to mate, and their reproductive attributes and the development and survival of their offspring would be better than that of young and old partners.

This study also aimed to assess: (i) the direct effect of male and/or female age on mating behaviour, reproduction and progeny fitness, and (ii) the indirect effect of individual mating behaviour (if any) on reproduction and progeny fitness (after correcting for the effect of male and female age).

\section{MATERIAL AND METHODS}

\section{Establishment of stock}

Adults of C. septempunctata ( $\mathrm{n}=40 ; 20 \hat{\mathrm{O}}$ and 20 ㅇ) and C. transversalis $\left(\mathrm{n}=40 ; 20 \hat{\delta^{\lambda}}\right.$ and 20 웅 ) were collected from agricultural fields adjoining Lucknow city $\left(26^{\circ} 50^{\prime} \mathrm{N}, 80^{\circ} 54^{\prime} \mathrm{E}\right)$ and used to establish a laboratory stock culture, which was kept in an environmental test chamber (CH-6S, Remi Instruments, Mumbai, India) maintained at $27 \pm 1^{\circ} \mathrm{C}, 65 \pm 5 \% \mathrm{RH}$ and a $14 \mathrm{~L}$ : $10 \mathrm{D}$ photoperiod. Ad libitum quantities of the aphid, Aphis craccivora Koch infesting the stems of cowpea (Vigna unguiculata L.) plants maintained in glasshouse $\left(23 \pm 1{ }^{\circ} \mathrm{C} ; 65 \pm 5 \% \mathrm{RH}\right.$ and $14 \mathrm{~L}$ : $10 \mathrm{D}$ photoperiod) were fed to the ladybirds, which were reared for three successive generations to acclimatize them to the laboratory conditions. In the first two generations, 06 ladybirds collected from fields were added per generation to the established stock culture in order to prevent inbreeding.

Males and females of the third generation were sexed and paired in Petri dishes $\left(9.0 \times 1.5 \mathrm{~cm}^{2}\right)$. The eggs were collected daily and egg hatch recorded. The larvae were reared in plastic beakers $\left(15.0 \times 12.0 \mathrm{~cm}^{2}\right.$; height $\times$ diameter $)$, which were replenished daily with a bean twig infested with an ad libitum supply of $A$. craccivora. The newly emerged adults were isolated and placed individually in Petri dishes for use in the experiments described below.

\section{Experimental design}

(i) Effect of age on mate choice

Unmated male and female adults of different ages (young: 10-15 days post-eclosion, middle aged: $30-40$ days, and old: $45-55$ days)
TABLE 1. The ages of the females and males mated in the nine different treatments used in the present study.

\begin{tabular}{cl}
\hline Treatment & Mating pair \\
\hline 1 & Young female $\times$ Young male \\
2 & Young female $\times$ Middle aged male \\
3 & Young female $\times$ Old male \\
4 & Middle aged female $\times$ Young male \\
5 & Middle aged female $\times$ Middle aged male \\
6 & Middle aged female $\times$ Old male \\
7 & Old female $\times$ Young male \\
8 & Old female $\times$ Middle aged male \\
9 & Old female $\times$ Old male \\
\hline
\end{tabular}

of C. septempunctata (120 $\hat{\jmath}$ and 120 per age group) and C. transversalis (120 $\hat{\sigma}^{\wedge}$ and 120 우 per age group) were used in following experiments. These age categories were selected based on the fact that even when supplied with an abundance of food the fecundity and egg viability of adults $10-15$ days, $30-40$ days and $45-55$ days post-eclosion differed. Also, beyond the age of 55 days, reproduction ceases in both these species (Bista \& Omkar, 2013, 2014).

To determine the effect of age on mate choice, young females of $C$. septempunctata and $C$. transversalis were each provided with males of three different age groups (young, middle aged and old) in a Petri dish $\left(9.0 \times 1.5 \mathrm{~cm}^{2}\right)$, which were then observed for $30 \mathrm{~min}$ and the male with which the female mated recorded. The mating pair was placed in another Petri dish and the other two males discarded. The same experiment was replicated 10 times per ladybird species.

Similar experiments were conducted using middle aged and old females, each of which was also replicated 10 times per ladybird species. Similar experiments were also done using males (either young, middle aged or old) simultaneously provided with three differently aged females (young, middle aged and old). The experiments were carried out under the same abiotic conditions as the stock culture. This resulted in nine treatments (Table 1).

\section{(ii) Effect of mate choice on mating behaviour}

In a normal mating sequence, males of $C$. septempunctata initiate a series of vertical thrusting movements with their abdomen soon after genital contact with the female. These are followed by wriggling movements (a gentle forward and backward movement of the abdomen with a simultaneous side-to-side component) and then a series of bouts of shaking (rapid lateral oscillations of the abdomen) between which they remain stationary. Thrusting and wriggling movements were observed only during the initial stages of mating. The mating behaviour of $C$. transversalis was similar, but did not involve thrusting (Michaud et al., 2013; Table 2).

The latent period, number of thrusts, duration of the wriggling movements, number of bouts, interval between successive bouts

TABLE 2. Features of the mating behaviour of the two ladybird species.

\begin{tabular}{ll}
\hline Features of the mating behaviour & Explanation \\
\hline Bouts & Rapid lateral oscillations of the abdomen \\
Latent period & Delay in the establishment of genital contact \\
Number of thrusts & Number of vertical thrusting movements with the abdomen \\
Duration of wriggling movements & Number of a gentle forward and backward movements of the abdomen with a simultaneous \\
& side-to-side component \\
Number of bouts & Number of rapid lateral oscillations of the abdomen \\
Interval between successive bouts & Period between two successive bouts \\
Duration of mating & Time taken to complete mating \\
\hline
\end{tabular}


and total duration of mating were recorded under a stereoscopic binocular microscope at $16 \times$ magnification for ten pairs randomly selected from each of the above nine mating treatments (totaling 90 pairs). In cases where fewer than 10 individuals mated in a particular treatment the number of replicates was increased until the appropriate number was recorded. The results of these mate choice experiments were however not included in the analysis.

(iii) Effect of mate choice on reproductive attributes

Every $24 \mathrm{~h}$, the males and females used in the above nine treatments per ladybird species [experiment (ii)] were allowed to mate for $2 \mathrm{~h}$ after which they were separated and reared individually in Petri dishes (size as above) and provided daily with an ad libitum supply of $A$. craccivora. Daily oviposition and egg hatching were recorded for the next 20 days.

(iv) Effect of mate choice on the development and survival of their offspring

The eggs of C. septempunctata and C. transversalis were randomly collected from each of above treatments [experiment (iii)] and their hatching recorded at $27^{\circ} \mathrm{C}$. One hundred newly emerged larvae from each treatment (totaling 900 larvae) were reared in beakers $(15.0 \times 12.0 \mathrm{~cm}$; height $\times$ diameter; 10 larvae per beaker $)$, which were replenished daily with bean twigs infested with an ad libitum supply of $A$. craccivora. The time of moulting of the larvae was recorded. Number surviving each moult and the duration of each larval instar was recorded. Observations were made every $24 \mathrm{~h}$ and the survival and durations of the different stages recorded. The total developmental period, percentage of larvae that pupated and percentage adult emergence were calculated.

\section{Statistical analysis}

All data were checked for normal distribution using Bartlett's test for normality and percentage data were subjected to arcsine square root transformation prior to analysis. The percentages of mating incidences in the different age combinations were analyzed using chi-square $\left(\chi^{2}\right)$ tests.

The dependent factors, mating behavioural attributes (latent period, number of thrusts, duration of wriggling movements, number of bouts, interval between successive bouts and total duration of mating), reproduction (fecundity and egg viability) and immature development and survival, were subjected to one way ANOVA, followed by Tukey's post hoc comparison of means, with age of males and females as independent factors.

In addition, the reproduction and progeny attributes (dependent factors) were individually subjected to an analysis of covariance (ANCOVA), followed by Tukey's post hoc comparison of means, with each mating behavioural attribute of the mating partners treated as independent factors and the age of the males and females as covariates (to nullify the confounding effect of age). Dependent factors were further regressed against the individual mating behavioural attributes. This was done to assess the indirect effect of mating behaviour on reproduction and progeny attributes. All analyses were done using statistical software MINITAB 16 (Minitab Inc., State College, Pennsylvania, USA).

\section{RESULTS}

\section{(i) Effect of age on mate choice}

The mate choice based on percentage mating revealed that young females of $C$. septempunctata $\left(\chi^{2}=11.55 ; \mathrm{P}<0.01\right)$ and C. transversalis $\left(\chi^{2}=9.50 ; \mathrm{P}<0.01\right)$ preferred middle aged males as mates over young and old males. Similarly, middle aged females preferred middle aged males as mates (C. septempunctata: $\chi^{2}=20.66 ; \mathrm{P}<0.01 ;$ C. transversalis: $\chi^{2}=17.55$;
TABLE 3. Age based mate choice by adults of $C$. septempunctat $a$ and $C$. transversalis (d.f. $=2 ; *$ and $* *$ denote F-values significant at $\mathrm{P}<0.05$ and $\mathrm{P}<0.01$, respectively; NS denotes $\chi^{2}$-values that are not significant, $\mathrm{P}>0.05$ ).

\begin{tabular}{|c|c|c|c|c|}
\hline \multicolumn{5}{|c|}{ C. septempunctata } \\
\hline Mate age & Young ${ }^{\lambda}$ & Middle $\widehat{\partial}$ & Old ${ }^{\lambda}$ & $\chi^{2}$ \\
\hline Young $ᄋ$ & 8 & 18 & 4 & $11.55^{* *}$ \\
\hline Middle $q$ & 6 & 21 & 3 & $20.66^{* *}$ \\
\hline Old $q$ & 11 & 14 & 5 & $4.66^{\mathrm{NS}}$ \\
\hline Mate age & Young 9 & Middle $q$ & Old 우 & $\chi^{2}$ \\
\hline Young $\widehat{o}$ & 9 & 17 & 4 & $9.55 * *$ \\
\hline Middle ${ }^{\lambda}$ & 6 & 20 & 4 & $16.88^{* *}$ \\
\hline Old $\hat{O}$ & 8 & 15 & 7 & $4.22^{\mathrm{NS}}$ \\
\hline \multicolumn{5}{|c|}{ C. transversalis } \\
\hline Mate age & Young $\hat{o}$ & Middle $\sigma^{\lambda}$ & Old ${ }^{\lambda}$ & $\chi^{2}$ \\
\hline Young $q$ & 11 & 16 & 3 & $9.50 * *$ \\
\hline Middle 우 & 7 & 20 & 3 & $17.55^{* *}$ \\
\hline Old + & 10 & 14 & 6 & $3.55^{\mathrm{NS}}$ \\
\hline Mate age & Young $q$ & Middle ${ }_{+}$ & Old $q$ & $\chi^{2}$ \\
\hline Young $\widehat{\partial}$ & 9 & 16 & 5 & $6.88^{*}$ \\
\hline Middle $\widehat{\partial}$ & 5 & 19 & 6 & $13.55^{* *}$ \\
\hline Old $\widehat{\sigma}$ & 9 & 14 & 7 & $2.88^{\mathrm{NS}}$ \\
\hline
\end{tabular}

$\mathrm{P}<0.01$ ). Old females did not show a significant preference for males of a particular age, mating with the first male they encountered (Table 3).

In both species, young males preferred middle aged females as mates over young and old females (C. septempunctata: $\chi^{2}=$ 9.55; $\mathrm{P}<0.01 ;$ C. transversalis: $\left.\chi^{2}=6.88 ; \mathrm{P}<0.05\right)$. Similarly, middle aged males showed a significant preference for middle aged females (C. septempunctata: $\chi^{2}=16.88 ; \mathrm{P}<0.01 ; C$. transversalis: $\left.\chi^{2}=13.55 ; \mathrm{P}<0.01\right)$. However, old males did not show a significant preference for mating with females of a particular age, mating with the first female they encountered. This study, therefore, indicates that middle aged females and males are the preferred mates (Table 3).

\section{(ii) Effect of the ages of the mating pair on their mating behaviour}

In both $C$. septempunctata and $C$. transversalis the latent period, number of thrusts (recorded only for C. septempunctata), duration of wriggling movements, number of bouts, interval between successive bouts and total duration of mating, did not vary significantly with the age of the female partner. However, the mating behaviour of male partners was significantly associated with their age. Tukey's post hoc comparison of means revealed that the numbers of thrusts recorded for males of different ages of $C$. septempunctata in the different mating treatments did not differ significantly $(\mathrm{F}=1.56 ; \mathrm{P}>$ 0.05). However, for males of different ages, the latent periods (C. septempunctata: $\mathrm{F}=3.83 ; \mathrm{P}<0.01 ;$ C. transversalis: $\mathrm{F}=$ 5.73; $\mathrm{P}<0.01)$, duration of wriggling movements $(C$. septempunctata: $\mathrm{F}=12.87 ; \mathrm{P}<0.01 ;$ C. transversalis: $\mathrm{F}=13.40 ; \mathrm{P}$ $<0.01$ ), number of bouts (C. septempunctata: $\mathrm{F}=17.46 ; \mathrm{P}<$ 0.01; C. transversalis: $\mathrm{F}=19.01 ; \mathrm{P}<0.01)$, interval between successive bouts (C. septempunctata: $\mathrm{F}=13.38 ; \mathrm{P}<0.01 ; C$. 
TABLE 4. Effect of mate age on the mating behaviour of $C$. septempunctata and $C$. transversalis (values are mean $\pm \mathrm{S} . \mathrm{E} . ; \mathrm{df}=22$, 89; * and $* *$ denote $\mathrm{F}$-values significant at $\mathrm{P}<0.05$ and $\mathrm{P}<0.01$, respectively; NS denotes $\mathrm{F}$-values that are not significant at $\mathrm{P}>0.05$; lower case letters are for comparison of means for males of different ages mating with females of a particular age).

\begin{tabular}{|c|c|c|c|c|c|c|c|}
\hline \multicolumn{2}{|c|}{ Mating pairs } & \multirow{2}{*}{$\begin{array}{l}\text { Latent period } \\
\text { (s) }\end{array}$} & \multirow{2}{*}{$\begin{array}{l}\text { Number } \\
\text { of thrusts }\end{array}$} & \multirow{2}{*}{$\begin{array}{c}\text { Duration of } \\
\text { wriggling move- } \\
\text { ments (min) }\end{array}$} & \multirow{2}{*}{$\begin{array}{l}\text { Number } \\
\text { of bouts }\end{array}$} & \multirow{2}{*}{$\begin{array}{l}\text { Interval b/w } \\
\text { successive } \\
\text { bouts (s) }\end{array}$} & \multirow{2}{*}{$\begin{array}{c}\text { Duration } \\
\text { of mating ( } \mathrm{min})\end{array}$} \\
\hline q Age & $\widehat{\jmath}$ Age & & & & & & \\
\hline \multicolumn{8}{|c|}{ C. septempunctata } \\
\hline \multirow{3}{*}{ Young } & Young & $8.03 \pm 0.23^{b}$ & $120.10 \pm 4.59^{b}$ & $26.50 \pm 1.62^{b}$ & $261.30 \pm 4.00^{\mathrm{b}}$ & $4.62 \pm 0.21^{b}$ & $67.80 \pm 2.76^{\mathrm{b}}$ \\
\hline & Middle aged & $7.50 \pm 0.22^{\mathrm{a}}$ & $125.00 \pm 3.14^{b}$ & $26.60 \pm 1.58^{b}$ & $287.00 \pm 4.53^{c}$ & $4.22 \pm 0.15^{\mathrm{a}}$ & $70.70 \pm 2.98^{b}$ \\
\hline & Old & $8.10 \pm 0.28^{c}$ & $92.90 \pm 4.57^{\mathrm{a}}$ & $20.00 \pm 1.75^{\mathrm{a}}$ & $196.60 \pm 9.96^{\mathrm{a}}$ & $5.17 \pm 0.18^{c}$ & $59.40 \pm 1.54^{\mathrm{a}}$ \\
\hline \multirow{3}{*}{ Middle } & Young & $8.13 \pm 0.20^{\mathrm{b}}$ & $122.20 \pm 4.01^{\mathrm{b}}$ & $24.50 \pm 1.83^{b}$ & $261.30 \pm 4.00^{\mathrm{b}}$ & $4.62 \pm 0.21^{b}$ & $65.70 \pm 1.78^{b}$ \\
\hline & Middle aged & $7.40 \pm 0.27^{\mathrm{a}}$ & $127.50 \pm 2.79^{b}$ & $27.40 \pm 1.72^{\mathrm{c}}$ & $297.10 \pm 6.92^{c}$ & $4.12 \pm 0.13^{\mathrm{a}}$ & $71.70 \pm 2.54^{\mathrm{c}}$ \\
\hline & Old & $8.60 \pm 0.27^{c}$ & $87.60 \pm 3.86^{\mathrm{a}}$ & $19.10 \pm 2.41^{\mathrm{a}}$ & $198.60 \pm 10.80^{\mathrm{a}}$ & $5.26 \pm 0.21^{\mathrm{c}}$ & $59.40 \pm 1.65^{\mathrm{a}}$ \\
\hline \multirow{3}{*}{ Old } & Young & $8.10 \pm 0.18^{b}$ & $112.50 \pm 5.19^{b}$ & $21.80 \pm 1.68^{c}$ & $250.80 \pm 5.86^{\mathrm{b}}$ & $4.71 \pm 0.17^{\mathrm{b}}$ & $65.50 \pm 1.96^{\mathrm{b}}$ \\
\hline & Middle aged & $7.70 \pm 0.15^{\mathrm{a}}$ & $121.60 \pm 4.24^{b}$ & $19.10 \pm 1.41^{\mathrm{a}}$ & $283.10 \pm 5.60^{c}$ & $4.22 \pm 0.19^{\mathrm{a}}$ & $69.40 \pm 2.96^{\mathrm{b}}$ \\
\hline & Old & $8.90 \pm 0.38^{\mathrm{c}}$ & $77.70 \pm 3.14^{\mathrm{a}}$ & $18.00 \pm 2.58^{\mathrm{a}}$ & $191.80 \pm 11.88^{\mathrm{a}}$ & $5.34 \pm 0.18^{c}$ & $57.80 \pm 1.36^{\mathrm{a}}$ \\
\hline \multicolumn{2}{|c|}{$\mathrm{F}^{\text {-age }}(\mathrm{P}$-value $)$} & $1.19^{\mathrm{NS}}$ & $1.31^{\mathrm{NS}}$ & $0.17^{\mathrm{NS}}$ & $0.31^{\mathrm{NS}}$ & $0.40^{\mathrm{NS}}$ & $0.31^{\mathrm{NS}}$ \\
\hline \multicolumn{2}{|c|}{$\mathrm{F}^{3}$-age (P-value) } & $3.83 * *$ & $1.56^{\mathrm{NS}}$ & $12.87^{* *}$ & $17.46^{* *}$ & $13.38^{* *}$ & $14.79^{* *}$ \\
\hline \multicolumn{8}{|c|}{ C. transversalis } \\
\hline \multirow{3}{*}{ Young } & Young & $8.17 \pm 0.21^{\mathrm{b}}$ & \multirow{11}{*}{ Absent } & $7.30 \pm 0.21^{b}$ & $148.20 \pm 6.49^{b}$ & $4.81 \pm 0.09^{b}$ & $24.60 \pm 1.34^{b}$ \\
\hline & Middle aged & $7.66 \pm 0.14^{\mathrm{a}}$ & & $8.60 \pm 0.27^{c}$ & $185.20 \pm 4.23^{c}$ & $4.18 \pm 0.11^{\mathrm{a}}$ & $28.70 \pm 1.56^{\mathrm{c}}$ \\
\hline & Old & $8.60 \pm 0.53^{c}$ & & $5.80 \pm 0.20^{\mathrm{a}}$ & $115.90 \pm 4.81^{\mathrm{a}}$ & $5.66 \pm 0.18^{\mathrm{c}}$ & $19.00 \pm 1.61^{\mathrm{a}}$ \\
\hline \multirow{3}{*}{ Middle } & Young & $7.79 \pm 0.32^{b}$ & & $7.50 \pm 0.17^{b}$ & $156.90 \pm 5.23^{b}$ & $4.68 \pm 0.10^{\mathrm{b}}$ & $24.90 \pm 1.64^{b}$ \\
\hline & Middle aged & $7.64 \pm 0.15^{\mathrm{a}}$ & & $8.60 \pm 0.31^{\mathrm{c}}$ & $200.70 \pm 6.69^{c}$ & $4.01 \pm 0.14^{\mathrm{a}}$ & $29.70 \pm 1.76^{c}$ \\
\hline & Old & $8.50 \pm 0.46^{\mathrm{c}}$ & & $6.20 \pm 0.25^{\mathrm{a}}$ & $121.10 \pm 5.18^{\mathrm{a}}$ & $5.50 \pm 0.12^{\mathrm{c}}$ & $19.30 \pm 1.52^{\mathrm{a}}$ \\
\hline \multirow{3}{*}{ Old } & Young & $8.36 \pm 0.28^{b}$ & & $7.20 \pm 0.20^{b}$ & $142.40 \pm 6.47^{b}$ & $4.93 \pm 0.08^{b}$ & $23.30 \pm 1.67^{\mathrm{b}}$ \\
\hline & Middle aged & $7.68 \pm 0.12^{\mathrm{a}}$ & & $8.40 \pm 0.16^{c}$ & $184.30 \pm 6.82^{\mathrm{c}}$ & $4.30 \pm 0.09^{\mathrm{a}}$ & $28.30 \pm 1.47^{\mathrm{c}}$ \\
\hline & Old & $8.60 \pm 0.58^{\mathrm{c}}$ & & $5.60 \pm 0.31^{\mathrm{a}}$ & $108.50 \pm 6.01^{\mathrm{a}}$ & $5.84 \pm 0.21^{\mathrm{c}}$ & $18.40 \pm 2.70^{\mathrm{a}}$ \\
\hline \multicolumn{2}{|c|}{$\mathrm{F}^{\text {q-age }}$ (P-value) } & $1.33^{\mathrm{NS}}$ & & $0.31^{\mathrm{NS}}$ & $0.23^{\mathrm{NS}}$ & $0.40^{\mathrm{NS}}$ & $0.17^{\mathrm{NS}}$ \\
\hline \multicolumn{2}{|c|}{$\mathrm{F}^{3 \text { age }}$ (P-value) } & $5.73 * *$ & & $13.40 * *$ & $19.01 * *$ & $12.74 * *$ & $16.21 * *$ \\
\hline
\end{tabular}

transversalis: $\mathrm{F}=12.74 ; \mathrm{P}<0.01)$ and total duration of mating (C. septempunctata: $\mathrm{F}=14.79 ; \mathrm{P}<0.01 ;$ C. transversalis: $\mathrm{F}$ $=16.21 ; \mathrm{P}<0.01)$ in both species differed significantly in the different mating treatments (Table 3). Comparison of means for both species revealed that the latent periods and intervals between successive bouts were shortest, numbers of bouts greatest, and duration of wriggling movements and total duration of mating longest for middle aged males, followed by young and old males (Table 4 ).

\section{(iii) Effect of the ages of the mating pair on reproduction}

In both $C$. septempunctata and $C$. transversalis, fecundity $(C$. septempunctata: $\mathrm{F}=22.69 ; \mathrm{P}<0.01 ; C$. transversalis: $\mathrm{F}=36.7 ; \mathrm{P}<0.01)$ and egg viability $(C$. septempunctata: $\mathrm{F}=14.91 ; \mathrm{P}<0.01 ;$ C. transversalis: $\mathrm{F}=14.78 ; \mathrm{P}<$ 0.01 ) differed significantly with the age of female and male partners, respectively. Fecundity and egg viability were highest for middle aged females and males; and lowest for old females and males, respectively (Table 5).

In addition to the significant influence of female and male age on fecundity and egg viability, respectively, analysis of covariance revealed a significant influence of cer- tain mating behavioural attributes on reproduction in both species, with a significant association between latent period and fecundity in both $C$. septempunctata and C. transversalis, but no clear trend in these two parameters (Figs 1 and 2). ANCOVA further revealed a significant association between the duration of wriggling movements, number of bouts, interval between successive bouts and total duration of mating and egg viability in both ladybirds. Egg viability increased with increase in the duration of wriggling movements and number of bouts in both species, and decreased with increase in the interval between successive bouts in C. transversalis. However, there was no clear association between egg viability and total duration of mating in either species; and between egg viability and the interval between successive bouts in C. septempunctata (Tables 5-6; Figs 1 and 2).

\section{(iv) Effect of the ages of the mating pair on the immature development and survival of their offspring}

In both species, percentage pupation (C. septempunctata: $\mathrm{F}=14.17 ; \mathrm{P}<0.01 ; C$. transversalis: $\mathrm{F}=10.01 ; \mathrm{P}<$ $0.01)$, percentage adult emergence (C. septempunctata: $\mathrm{F}$ $=12.79 ; \mathrm{P}<0.01 ;$ C. transversalis: $\mathrm{F}=13.62 ; \mathrm{P}<0.01)$ 

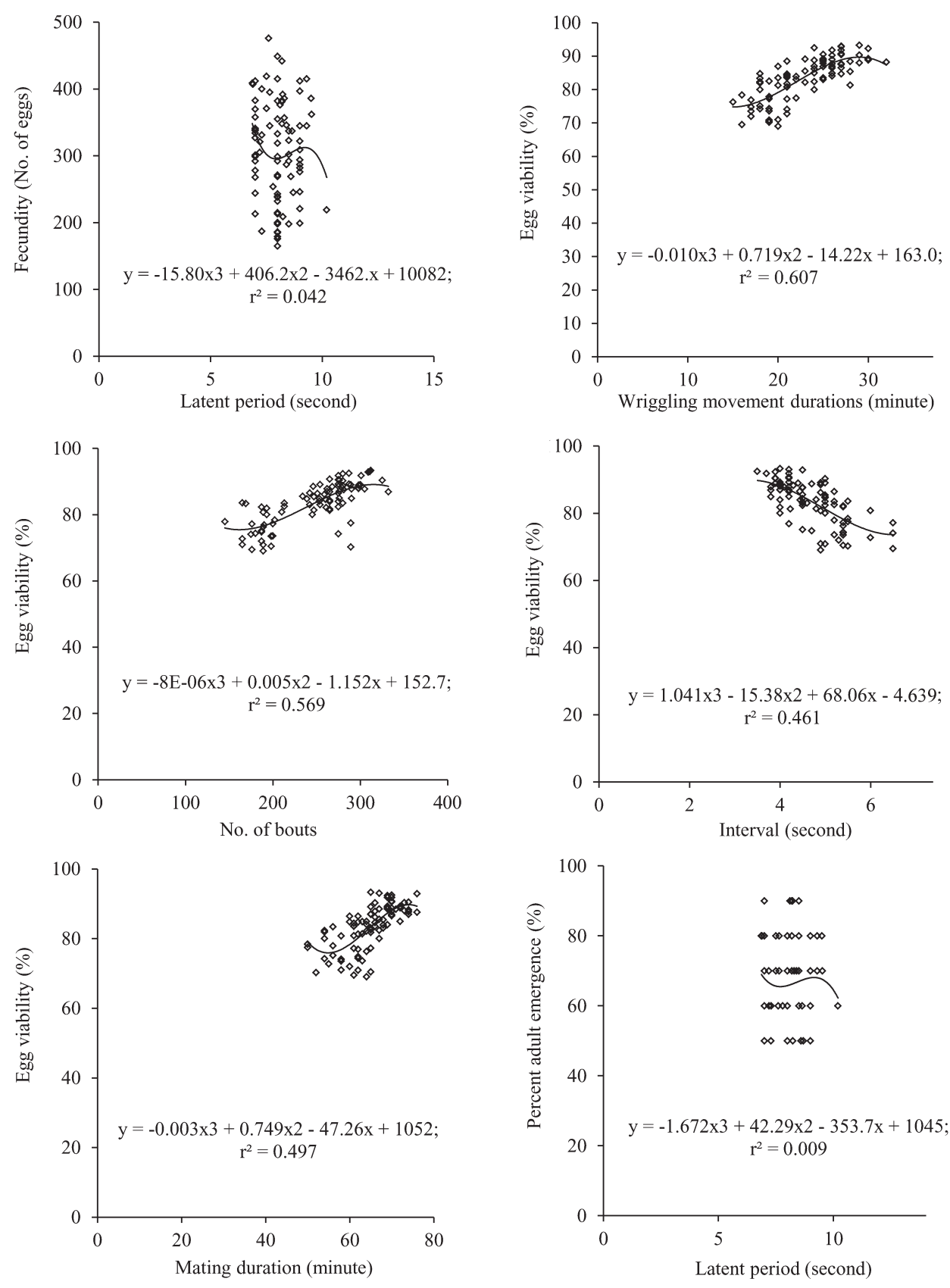

Fig. 1. Associations between mating behaviour and the reproductive and progeny attributes of C. septempunctata $\left(\mathrm{r}^{2}\right.$-values $\geq 0.50$ have Pvalues $<0.05$ and indicate strong associations between the parameters; while $\mathrm{r}^{2}$-values $<0.50$ have P-values $\geq 0.05$ and indicate weak associations between the parameters).

and total duration of development (C. septempunctata: $\mathrm{F}$ $=13.77 ; \mathrm{P}<0.01 ;$ C. transversalis: $\mathrm{F}=19.43 ; \mathrm{P}<0.01)$ of the immature stages depended significantly on the age of the female, but not of the male. Percentage pupation and percentage adult emergence were highest and the total duration of development of immature stages shortest for middle aged females, whereas fewer of the progeny of old females survived and took much longer to complete their development (Table 5).

ANCOVA further revealed a significant association between the latent period and percentage adult emergence in both species, but no clear trend between percentage adult emergence and latent period (Tables 5-6; Figs 1 and 2).

\section{DISCUSSION}

In both $C$. septempunctata and $C$. transversalis the age of the adults affected their choice of mates, fecundity and the development and survival of their progeny. Results revealed that middle aged males were the preferred mates of young, middle aged and old females of both species. Similarly, males of all ages preferred middle aged females, probably because such a choice increases their fitness. Moreover, old mates were avoided by both males and females. A decline in mating and fertilization success beyond a certain age was recorded in the present study and is reported for a wide range of insects (Price \& Hansen, 1998; Jones et al., 2000; Kidd et al., 2001; Bonduriansky 

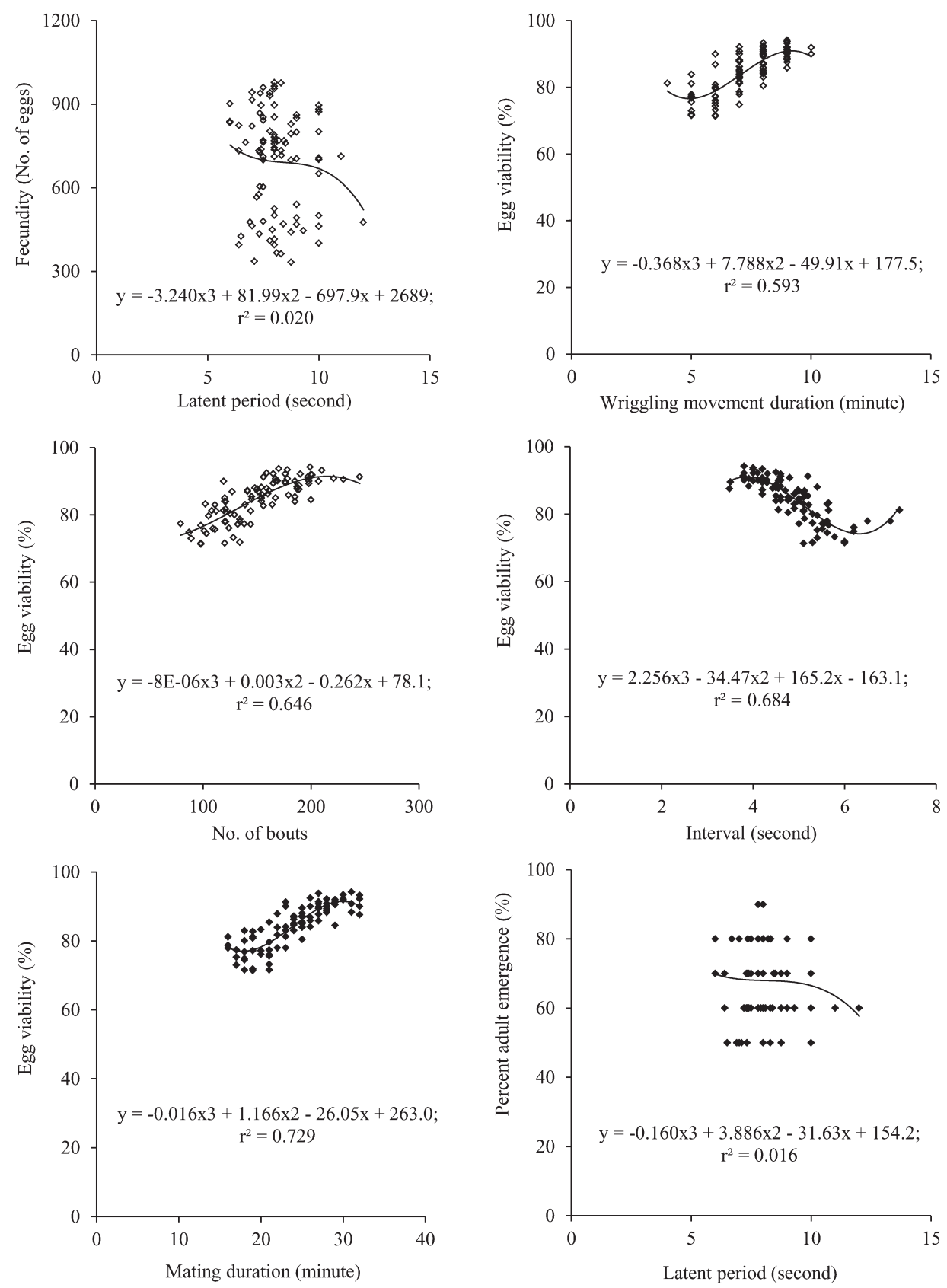

Fig. 2. Associations between mating behaviour and the reproductive and progeny attributes of $C$. transversalis $\left(r^{2}\right.$-values $\geq 0.50$ have $P$-values $<0.05$ and indicate strong associations between the parameters; while $\mathrm{r}^{2}$-values $<0.50$ have $\mathrm{P}$-values $\geq 0.05$ and indicate weak associations between the parameters).

\& Brassil, 2002; Jones \& Elgar, 2004; Beck \& Promislow, 2007; Omkar et al., 2010). In contrast, there are studies that report a high female preference for old males (Proulx et al., 2002; Avent et al., 2008).

How adults perceive a potential partner's age is not known in ladybirds, but visual cues do not seem to play a role. Perhaps a pheromone(s) is accumulated inside the body and then secreted, which helps both sexes to perceive a potential partner's age. Probably middle aged males and females produce and secrete higher concentrations of the pheromone(s) that act as chemical cues for the opposite sex and helps them determine the age of potential partners. However, in young and old adults, probably the production of the pheromone(s) is either very low or has ceased and as a consequence they are less preferred as potential mates. The early production of sex pheromones and their role in regulating courtship behaviour has been studied in Drosophila melanogaster (Moulin et al., 2004).

Females that prefer and mate with middle-aged males probably benefit by an increase in fecundity and egg viability, and/ or faster development of their offspring compared with those that mate with old males. Moreover, the trade-off model proposed by Beck et al. (2002) suggests that females should prefer to mate with middle aged males as their reproductive attributes are greater than those of old males. In contrast, some empirical evidence indicates that young males are of higher quality than middle aged and/or old males (Price \& Hansen, 1998; Pervez et al., 2004). However, female preference for old males 
TABLE 5. Effect of mate age on the reproductive attributes, and immature development and survival of their offspring for C. septempunctata and $C$. transversalis (d.f. $=22,89$; values are mean \pm S.E.; values followed by different lower case letters are significantly different; * and ** denote F-values significant at $\mathrm{P}<0.05$ and $\mathrm{P}<0.01$, respectively; NS denotes F-values that are not significant at $\mathrm{P}>0.05$; lower case letters are for the comparison of the means for males of different ages mating with females of a particular age).

\begin{tabular}{|c|c|c|c|c|c|c|}
\hline \multicolumn{2}{|c|}{ Mating pairs } & \multirow{2}{*}{$\begin{array}{c}\text { Fecundity } \\
\text { (No. of eggs) }\end{array}$} & \multirow{2}{*}{$\begin{array}{l}\text { Egg viability } \\
(\%)\end{array}$} & \multirow{2}{*}{ Pupation (\%) } & \multirow{2}{*}{$\begin{array}{c}\text { Adult emergence } \\
(\%)\end{array}$} & \multirow{2}{*}{$\begin{array}{c}\text { Total duration } \\
\text { of development (days) }\end{array}$} \\
\hline q Age & $\hat{\delta}$ Age & & & & & \\
\hline \multicolumn{7}{|c|}{ C. septempunctata } \\
\hline \multirow{3}{*}{ Young } & Young & $322.80 \pm 9.42^{\mathrm{a}}$ & $84.08 \pm 1.52^{\mathrm{b}}$ & $72.00 \pm 1.33^{\mathrm{ab}}$ & $66.00 \pm 1.63^{\mathrm{a}}$ & $15.73 \pm 1.22^{\mathrm{a}}$ \\
\hline & Middle & $328.80 \pm 11.35^{\mathrm{a}}$ & $89.21 \pm 2.57^{c}$ & $74.00 \pm 1.63^{\mathrm{b}}$ & $68.00 \pm 2.00^{\mathrm{a}}$ & $15.45 \pm 1.20^{\mathrm{a}}$ \\
\hline & Old & $299.30 \pm 8.83^{b}$ & $76.37 \pm 1.18^{\mathrm{a}}$ & $71.00 \pm 1.00^{\mathrm{a}}$ & $65.00 \pm 1.67^{\mathrm{a}}$ & $15.99 \pm 1.21^{\mathrm{a}}$ \\
\hline \multirow{3}{*}{ Middle } & Young & $382.10 \pm 11.77^{\mathrm{a}}$ & $85.92 \pm 2.86^{b}$ & $82.00 \pm 2.00^{\mathrm{a}}$ & $77.00 \pm 2.60^{\mathrm{ab}}$ & $14.44 \pm 1.18^{\mathrm{a}}$ \\
\hline & Middle & $400.10 \pm 13.21^{\mathrm{b}}$ & $90.01 \pm 1.64^{\mathrm{c}}$ & $83.00 \pm 2.13^{\mathrm{a}}$ & $81.00 \pm 3.14^{b}$ & $14.24 \pm 1.18^{\mathrm{a}}$ \\
\hline & Old & $374.20 \pm 9.45^{\mathrm{a}}$ & $78.26 \pm 1.28^{\mathrm{a}}$ & $81.00 \pm 1.80^{\mathrm{a}}$ & $76.00 \pm 1.63^{\mathrm{a}}$ & $14.60 \pm 1.20^{\mathrm{a}}$ \\
\hline \multirow{3}{*}{ Old } & Young & $224.60 \pm 13.25^{\mathrm{ab}}$ & $83.95 \pm 2.68^{b}$ & $62.00 \pm 1.33^{\mathrm{a}}$ & $56.00 \pm 2.21^{\mathrm{ab}}$ & $17.17 \pm 1.25^{\mathrm{a}}$ \\
\hline & Middle & $236.80 \pm 10.75^{\mathrm{b}}$ & $88.73 \pm 2.69^{c}$ & $64.00 \pm 1.63^{\mathrm{a}}$ & $58.00 \pm 1.33^{\mathrm{b}}$ & $17.70 \pm 1.33^{\mathrm{a}}$ \\
\hline & Old & $207.80 \pm 5.07^{\mathrm{a}}$ & $74.92 \pm 1.39^{a}$ & $62.00 \pm 2.00^{\mathrm{a}}$ & $54.00 \pm 1.63^{\mathrm{a}}$ & $17.44 \pm 1.21^{\mathrm{a}}$ \\
\hline \multicolumn{2}{|c|}{$\mathrm{F}^{\text {q-age }}(\mathrm{P}$-value $)$} & $22.69 * *$ & $0.25^{\mathrm{NS}}$ & $14.17 * *$ & $12.79 * *$ & $13.77 * *$ \\
\hline \multicolumn{2}{|c|}{$\mathrm{F}^{3}$-age (P-value) } & $0.19 \mathrm{NS}$ & $14.91^{* *}$ & $0.34^{\mathrm{NS}}$ & $0.40^{\mathrm{NS}}$ & $0.23^{\mathrm{NS}}$ \\
\hline \multicolumn{7}{|c|}{ C. transversalis } \\
\hline \multirow{3}{*}{ Young } & Young & $739.30 \pm 10.06^{\mathrm{ab}}$ & $85.86 \pm 1.83^{b}$ & $70.00 \pm 1.49^{\mathrm{a}}$ & $68.00 \pm 2.00^{\mathrm{a}}$ & $15.37 \pm 1.24^{\mathrm{a}}$ \\
\hline & Middle & $767.90 \pm 13.03^{\mathrm{b}}$ & $90.68 \pm 2.73^{c}$ & $72.00 \pm 1.33^{\mathrm{a}}$ & $69.00 \pm 2.33^{\mathrm{a}}$ & $15.26 \pm 1.22^{\mathrm{a}}$ \\
\hline & Old & $732.50 \pm 16.39^{a}$ & $77.44 \pm 1.25^{\mathrm{a}}$ & $70.00 \pm 1.49^{\mathrm{a}}$ & $66.00 \pm 2.21^{\mathrm{a}}$ & $15.54 \pm 1.22^{\mathrm{a}}$ \\
\hline \multirow{3}{*}{ Middle } & Young & $871.80 \pm 24.17^{\mathrm{ab}}$ & $87.50 \pm 1.53^{b}$ & $82.00 \pm 1.33^{\mathrm{ab}}$ & $78.00 \pm 2.00^{\mathrm{ab}}$ & $13.79 \pm 1.18^{\mathrm{a}}$ \\
\hline & Middle & $893.00 \pm 26.61^{b}$ & $91.11 \pm 2.64^{c}$ & $85.00 \pm 1.67^{\mathrm{b}}$ & $81.00 \pm 1.80^{\mathrm{b}}$ & $13.57 \pm 1.23^{\mathrm{a}}$ \\
\hline & Old & $858.60 \pm 15.54^{\mathrm{a}}$ & $78.19 \pm 1.05^{\mathrm{a}}$ & $81.00 \pm 1.00^{\mathrm{a}}$ & $77.00 \pm 1.53^{\mathrm{a}}$ & $13.91 \pm 1.20^{\mathrm{a}}$ \\
\hline \multirow{3}{*}{ Old } & Young & $465.10 \pm 21.01^{b}$ & $84.28 \pm 1.80^{\mathrm{b}}$ & $63.00 \pm 1.53^{\mathrm{a}}$ & $57.00 \pm 1.53^{\mathrm{ab}}$ & $16.90 \pm 1.17^{\mathrm{a}}$ \\
\hline & Middle & $494.30 \pm 25.36^{\mathrm{b}}$ & $89.84 \pm 2.69^{c}$ & $64.00 \pm 1.63^{\mathrm{a}}$ & $59.00 \pm 1.80^{\mathrm{b}}$ & $17.25 \pm 0.16^{\mathrm{b}}$ \\
\hline & Old & $417.00 \pm 20.44^{\mathrm{a}}$ & $76.04 \pm 1.10^{\mathrm{a}}$ & $61.00 \pm 2.33^{\mathrm{a}}$ & $55.00 \pm 1.67^{\mathrm{a}}$ & $17.16 \pm 1.21^{\mathrm{b}}$ \\
\hline \multicolumn{2}{|c|}{$\mathrm{F}^{\text {q-age }}(\mathrm{P}$-value $)$} & $36.77 * *$ & 0.23 Ns & $10.01 * *$ & $13.62 * *$ & $19.43 * *$ \\
\hline \multicolumn{2}{|c|}{$\mathrm{F}^{\delta \text {-age }}$ (P-value) } & $0.09^{\mathrm{NS}}$ & $14.78^{* *}$ & $0.36^{\mathrm{NS}}$ & $0.45^{\mathrm{NS}}$ & $0.20^{\mathrm{NS}}$ \\
\hline
\end{tabular}

has been ascribed to a positive correlation between male age and values of sexually selected traits (Hansen \& Price, 1995). Thus, female preference for old males does not necessarily support the idea that it evolved due to "good genes" (Hansen \& Price, 1995).

Similarly, young and middle aged males preferred to mate with middle aged females. Although, it might be more advantageous for a male to mate with a young female because: (i) she has a longer oviposition period than middle aged/old females, and could thus potentially keep using sperm for longer and (ii) even if a middle-aged female offered benefits in the short term, owing to an immediate higher fecundity or reduced sperm competition (Bonduriansky, 2001), it is possible that her potential longer life is the most important. However, the greater preference of males for middle aged females is probably because it results in their producing higher quality rather than a greater number of offspring.

The preference of mates also affected their reproductive behaviour. The duration of wriggling movements, numbers of bouts and duration of mating were longest and the latent periods and bout intervals shortest when middle aged males were the mates. The reverse was true for old males. This probably indicates that: (a) they ejaculate more sperm (Bonduriansky, 2001), and (b) guard mates in order to avoid sperm competition (Parker, 1974). The increased transfer of seminal fluid may be attributed to: (a) preferential transfer, and/or (b) the preferred males have more sperm (Ueno, 1994). Both young and old males probably ejaculate significantly lower quality and less sperm than middle aged males (Jones \& Elgar, 2004), which is possibly associated with their mating for a shorter time with fewer wriggling movements and bouts. Thus, the more prolonged mating by middle aged males may result in the ejaculation of a greater quantity of sperm into the spermathecae of females, which can fertilize the ova when males are not available and may result in increased lifetime viability (Pervez et al., 2004).

In the present study, fecundity was significantly associated with female age and egg viability with male age. Fecundity and egg viability were highest for middle aged females and males and lowest for old females and males, respectively. The greater fecundity and egg viability of middle aged females and males may be ascribed to the availability of a greater number of mature ova and better quality sperm (Obata, 1988). Similar 
TABLE 6. Effect of mating behaviour on the reproductive attributes, and the immature development and survival of their offspring for C. septempunctata and $C$. transversalis considering female and male age as covariates $(*$ and $* *$ denote $\mathrm{F}$-values that are significant at $\mathrm{P}<0.05$ and $\mathrm{P}<0.01$, respectively; NS denotes F-values that are not significant at $\mathrm{P}>0.05 ; \mathrm{LP}, \mathrm{S}, \mathrm{WMD}, \mathrm{NB}, \mathrm{I}$ and MD represent latent period, number of thrusts, duration of wriggling movements, number of bouts, interval and duration of mating, respectively).

\begin{tabular}{|c|c|c|c|c|c|}
\hline+ Age $\curvearrowright$ Age & $\begin{array}{c}\text { Fecundity } \\
\text { (No. of eggs) }\end{array}$ & $\begin{array}{c}\text { Egg viability } \\
(\%)\end{array}$ & Pupation (\%) & Adult emergence (\%) & $\begin{array}{c}\text { Total duration } \\
\text { of development (days) }\end{array}$ \\
\hline \multicolumn{6}{|c|}{ C. septempunctata } \\
\hline$F^{L P}$ (d.f.) & $2.05 *(26,89)$ & $1.37^{\mathrm{NS}}(26,89)$ & 1.41 Ns $(26,89)$ & $1.70 *(26,89)$ & $1.25^{\mathrm{NS}}(26,89)$ \\
\hline $\mathrm{F}^{\mathrm{s}}$ (d.f.) & $0.71^{\mathrm{NS}}(34,89)$ & $0.95^{\mathrm{NS}}(34,89)$ & $0.92^{\mathrm{NS}}(34,89)$ & $0.91^{\mathrm{NS}}(34,89)$ & $0.77^{\mathrm{NS}}(34,89)$ \\
\hline F wMD (d.f.) & $1.00^{\mathrm{NS}}(16,89)$ & $7.32 * *(16,89)$ & $0.54{ }^{\mathrm{NS}}(16,89)$ & $0.37^{\mathrm{NS}}(16,89)$ & $0.48^{\mathrm{NS}}(16,89)$ \\
\hline$F^{N B}$ (d.f.) & $0.69^{\mathrm{NS}}(47,89)$ & $2.04 *(47,89)$ & 0.72 Ns $(47,89)$ & 0.77 Ns $(47,89)$ & 0.74 Ns $(47,89)$ \\
\hline $\mathrm{F}^{\mathrm{I}}$ (d.f.) & $1.11^{\mathrm{NS}}(23,89)$ & $2.85^{* *}(23,89)$ & $1.23^{\mathrm{NS}}(23,89)$ & $0.92^{\mathrm{NS}}(23,89)$ & $1.22^{\mathrm{NS}}(23,89)$ \\
\hline$F^{M D}$ (d.f.) & 0.92 NS $(21,89)$ & $4.29 * *(21,89)$ & $0.50 \mathrm{NS}(21,89)$ & $0.55^{\mathrm{NS}}(21,89)$ & $0.88^{\mathrm{NS}}(21,89)$ \\
\hline \multicolumn{6}{|c|}{ C. transversalis } \\
\hline$F^{L P}$ (d.f.) & $0.76^{\mathrm{NS}}(29,89)$ & $3.65^{* *}(29,89)$ & 1.04 Ns $(29,89)$ & $0.79^{\mathrm{NS}}(29,89)$ & 0.91 NS $(29,89)$ \\
\hline$F^{\text {WMD }}$ (d.f.) & $1.17^{\mathrm{NS}}(6,89)$ & $16.06^{* *}(6,89)$ & $1.73^{\mathrm{NS}}(6,89)$ & $0.94^{\mathrm{NS}}(6,89)$ & $0.52^{\mathrm{NS}}(6,89)$ \\
\hline$F^{N B}$ (d.f.) & $0.79^{\mathrm{NS}}(57,89)$ & $3.83 * *(57,89)$ & 0.71 Ns $(57,89)$ & $0.80^{\mathrm{NS}}(57,89)$ & $0.80^{\mathrm{NS}}(57,89)$ \\
\hline $\mathrm{F}^{\mathrm{I}}$ (d.f.) & 0.62 NS $(36,89)$ & $4.60 * *(36,89)$ & $0.74{ }^{\mathrm{NS}}(36,89)$ & $0.62 \mathrm{NS}(36,89)$ & $0.62 \mathrm{NS}(36,89)$ \\
\hline $\mathrm{F}^{\mathrm{MD}}$ (d.f.) & $0.81^{\mathrm{NS}}(16,89)$ & $11.11 * *(16,89)$ & $1.12^{\mathrm{NS}}(16,89)$ & $1.55^{\mathrm{NS}}(16,89)$ & $0.81^{\mathrm{NS}}(16,89)$ \\
\hline
\end{tabular}

findings were also reported earlier (Mishra \& Omkar, 2004; Pervez et al., 2004; Pandey \& Omkar, 2013). However, the females that mate at a young age start ovipositing later probably because their immature gonads take some time to mature (Hemptinne et al., 2001). The decline in fecundity and egg viability with age is indicative of ladybird senescence (Srivastava \& Omkar, 2004), which results in the deterioration of their reproductive organs in old age (Dixon \& Agarwala, 2002; Srivastava \& Omkar, 2004). Age-related decline in sperm quantity and viability has been attributed to general senescence or accumulation of germ line mutations in old individuals (Kidd et al., 2001; Szczesny et al., 2003). Old age or delayed mating resulted in reduced reproductive potential, as is also reported in female cockroaches (Moore \& Moore, 2001), hide beetles, Dermestes maculatus DeGeer (Jones \& Elgar, 2004), the oriental beetle, Anomala orientalis Waterhouse (Wenninger \& Averill, 2006) and the bean weevil, Acanthoscelides obtectus Say (Maklakov et al., 2007).

Percentage pupation and adult emergence were highest and the developmental time of their offspring shortest for middle aged females of $C$. septempunctata and $C$. transversalis. The shorter total developmental periods for the offspring of middle aged females are similar to those reported by Fox (1993) and Fox et al. (2003) for the seed beetle, Callosobruchus maculatus (F.). The opposite was recorded for the offspring of old parents. This is probably due to the increased incidence of mutations in old parents, as suggested by various ageing theories (Medawar, 1952; Hamilton, 1966; Partridge \& Barton, 1993; Pletcher \& Curstinger, 1998). The prolonged development of the offspring of old parents is similar to that recorded for Drosophila melanogaster (Mills \& Goldstein, 1985), stink bugs, Podisus nigrispinous (Dallas) and Podisus maculiventris (Say) (Mohaghegh et al., 1998) and the cockroach, Nauphoeta cinerea (Olivier) (Moore \& Harris, 2003).

The significant associations of: (i) the latent period with fecundity, (ii) duration of wriggling movements, number of bouts, interval between successive bouts and total duration of mating with egg viability, and (iii) latent period with percentage adult emergence, indicate that the reproductive and progeny attributes are a function of the age of the mates and their sexual activity. Middle aged females may have a higher number of ova to mature, while middle aged males may transfer better quality and more sperm, which probably enhances their reproductive and progeny attributes.

In brief, (i) middle aged mates of both species were preferred by young, middle aged and old adults; (ii) mating behaviour and egg viability were significantly associated with male age; while female age was significantly associated with fecundity and the duration of development and survival of their offspring; (iii) shortest latent periods and bout intervals, highest numbers of bouts, longest duration of wriggling movements and mating, and maximum egg viability were recorded for middle aged males; while the fecundity, percentage pupation and adult emergence were highest and duration of immature development shortest for middle aged females. Thus, the results of the present study indicate that for the fast production of these species in the laboratory for use in the augmentative biocontrol of aphids it would be best to use middle aged individuals of $C$. septempunctata and C. transversalis.

ACKNOWLEDGEMENTS. M. Bista thanks the UGC, Nepal for financial assistance. Omkar thanks the Department of Higher Education, Government of Uttar Pradesh for financial assistance under the Centre of Excellence programme.

\section{REFERENCES}

Andersson M. 1994: Sexual Selection. Princeton University Press, Princeton, 624 pp.

Andersson M. \& Simmons L.W. 2006: Sexual selection and mate choice. - Trends Ecol. Evol. 21: 296-302.

Arnqvist G. \& Nilsson T. 2000: The evolution of polyandry: multiple matings and female fitness in insects. - Anim. Behav. 60: $145-164$ 
Avent T.D., Price T.A.R. \& Wedell N. 2008: Age-based female preference in the fruit fly Drosophila pseudoobscura. — Anim. Behav. 75: 1413-1421.

BECK C.W. \& Promislow D.E.L. 2007: Evolution of female preference for younger males. - PLOS ONE 2: 939.

Beck C.W., Shapiro B., ChoKsi S. \& Promislow D.E.L. 2002: A genetic algorithm approach to study the evolution of female preference based on male age. - Evol. Ecol. Res. 4: 275-292.

BiRKInSHAW L.A. \& SMith R.H. 2001: Prostephanus truncatus mate choice on contact: does pheromone signalling by males affect their mating success? - Entomol. Exp. Appl. 98: 345351.

BisTA M. \& OMKAR 2013: Effects of body size and prey quality on reproductive attributes of two aphidophagous ladybird beetles (Coleoptera: Coccinellidae). - Can. Entomol. 145: 566-576.

BISTA M. \& OMKAR 2014: Consumption, developmental and reproductive attributes of two con-generic ladybird predators under variable prey supply. - Biol. Contr. 74: 36-44.

BonduRIANSKY R.A. 2001: The evolution of male mate choice in insects: a synthesis of ideas and evidence. - Biol. Rev. Cam. Philos. Soc. 76: 305-339.

Bonduriansky R.A. \& BrassiL C.E. 2002: Rapid and costly ageing in wild male flies. - Nature 420: 377.

Bonduriansky R. \& Brooks R.J. 1998: Male antleries (Protopiophila litigata; Diptera: Piophilidae) are more selective than females in mate choice. - Can. J. Zool. 76: 1277-1285.

Borg A.A., Forsgren E. \& Amundsen T. 2006: Seasonal change in female choice for male size in the two-spotted goby. Anim. Behav. 72: 763-771.

Dixon A.F.G. \& Agarwala B.K. 2002: Triangular fecundity function and ageing in ladybird beetles. - Ecol. Entomol. 27: 433-440.

Fedina T. \& Lewis S.M. 2008: An integrative view of sexual selection in Tribolium flour beetles. - Biol. Rev. Cam. Philos. Soc. 83: 151-171.

Fox C.W. 1993: Multiple mating, lifetime fecundity and female mortality of the bruchid beetle, Callosobruchus maculatus (Coleoptera: Bruchidae). - Funct. Ecol. 7: 203-208.

Fox C.W., Bush M.L. \& Wallin W.G. 2003: Maternal age affects offspring lifespan of the seed beetle, Callosobruchus maculatus. - Funct. Ecol. 17: 811-820.

Gamble S., Lindholm A.K., Endler J.A. \& Brooks R. 2003: Environmental variation and the maintenance of polymorphism: the effect of ambient light spectrum on the mating behaviour and sexual selection in guppies. - Ecol. Lett. 6: 463-472.

Gavrilets S., Arnqvist G. \& Friberg U. 2001: The evolution of female mate choice by sexual conflict. - Proc. R. Soc. (B) 268: 531-539.

HamiLton W.D. 1966: The moulding of senescence by natural selection. - J. Theor. Biol. 12: 12-45.

Hansen T.F. \& Price D.K. 1995: Good genes and old age: do old mates provide superior genes? - J. Evol. Biol. 8: 769-778.

Hemptinne J.L., Dixon A.F.G. \& Adam B. 2001: Do males and females of the two-spot ladybird, Adalia bipunctata (L.) differ in when they mature sexually? - J. Insect Behav. 14: 411-419.

Hodek I. \& Michaud J.P. 2008: Why is Coccinella septempunctata so successful? - Eur. J. Entomol. 105: 1-12.

Holland B. \& Rice W.R. 1998: Perspective: Chase-away sexual selection: antagonistic seduction versus resistance. - Evolution 52: 1-7.

Jennions M.D. \& Petrie M. 1997: Variation in mate choice and mating preferences: a review of causes and consequences. Biol. Rev. Cam. Philos. Soc. 72: 283-327.

Jennions M.D. \& Petrie M. 2000: Why do females mate multiply? A review of the genetic benefits. - Biol. Rev. 75: 21-64.
Johnstone R.A., Reynolds J.D. \& Deutsch J.C. 1996: Mutual mate choice and sex differences in choosiness. - Evolution 50: $1382-1391$.

Jones T.M. \& Elgar M.A. 2004: The role of male age, sperm age and mating history on fecundity and fertilization success in the hide beetle. - Proc. R. Soc. (B) 271: 1311-1318.

Jones T.M., BALmFord A. \& QuinNell R.J. 2000: Adaptive female choice for middle-aged mates in a lekking sandfly. - Proc. $R$. Soc. (B) 267: 681-686.

Kid S.A., Eskenazl B. \& Wyrobek A.J. 2001: Effects of male age on semen quality and fertility: a review of the literature. Fertil. Steril. 75: 237-248.

KiRKPATRICK M. \& RYAN M.J. 1991: The evolution of mating preferences and the paradox of the lek. - Nature 350: 33-38.

Kumar B., Mishra G. \& Omkar 2014: Functional response and predatory interactions in conspecific and heterospecific combinations of two congeneric species (Coleoptera: Coccinellidae). - Eur. J. Entomol. 111: 257-265.

Maklakov A.A., Kremer N. \& Arnqvist G. 2007: The effects of age at mating on female life history traits in a seed beetle. Behav. Ecol. 18: 551-555.

Mautz B.S. \& SaKaluK S.K. 2008: The effects of age and previous mating experience on pre- and post-copulatory mate choice in female house crickets (Acheta domesticus L.). - J. Insect Behav. 21: 203-212.

McNamara K.B., Jones T.M. \& Elgar M.A. 2004: Female reproductive status and mate choice in the hide beetle, Dermestes maculatus. - J. Insect Behav. 17: 337-352.

Medawar P.B. 1952: An Unsolved Problem of Biology. H.K. Lewis, London, $24 \mathrm{pp}$.

Michaud J.P., Bista M., Mishra G. \& OMkar 2013: Sexual activity diminishes male virility in two Coccinella species: consequences for female fertility and progeny development. — Bull. Entomol. Res. 103: 570-577.

Mills A. \& Goldstein I.H. 1985: Maternal age, development time, position effect variegation in Drosophila melanogaster. - Genet. Sel. Evol. 17: 171-178.

Mishra G. \& OMKAR 2004: Influence of parental age on reproductive performance of an aphidophagous ladybird, Propylea dissecta (Mulsant). - J. Appl. Entomol. 128: 605-609.

Mishra G. \& OmKar 2014: Phenotype-dependent mate choice in Propylea dissecta and its fitness consequences. - J. Ethol. 32: 165-172.

Mohaghegh J., ClercQ P.D. \& Tirry L. 1998: Effects of maternal age and egg weight on developmental time and body weight of offspring of Podisus maculiventris (Heteroptera: Pentatomidae). - Ann. Entomol. Soc. Am. 91: 315-322.

MoORE P.J. \& HARRIS W.E. 2003: Is a decline in offspring quality a necessary consequence of maternal age? - Proc. R. Soc. (B) 270: 192-194.

Moore P.J. \& Moore A.J. 2001: Reproductive ageing and mating: the ticking of the biological clock in female cockroaches. Proc. Natl. Acad. Sci. USA 98: 9171-9176.

Moulin B., Aubin T. \& JALlon J.M. 2004: Why there is a one-way crossability between $D$. melanogaster and $D$. simulans? An ontogenic explanation. - Genetica 120: 285-292.

Овата S. 1988: Mating behaviour and sperm transfer in the ladybird beetle, Harmonia axyridis Pallas (Coleoptera: Coccinellidae). - Appl. Entomol. Zool. 22: 434-442.

OMKAR \& BIND R.B. 1993: Records of aphid-natural enemies complex of Uttar Pradesh II. The Coccinellids. - J. Adv. Zool. 14: 96-99.

OMKAR \& Pervez A. 2002: Ecology of aphidophagous ladybird beetle, Coccinella septempunctata Linn. (Coleoptera: Coccinellidae): A review. — J. Aphidol. 16: 175-201. 
OMKar \& Pervez A. 2005: Mating behaviour of aphidophagous ladybird beetle, Propylea dissecta (Mulsant). - Insect Sci. 12: $37-44$.

OMKAR \& SinGH S.K. 2010: Mating behaviour of the aphidophagous ladybird beetle Coelophora saucia (Coleoptera: Coccinellidae). - Int. J. Trop. Insect Sci. 30: 3-10.

Omkar, Pandey P., Rastogi S. \& Mishra G. 2010: Influence of age at mating on the reproductive performance of Parthenium beetle, Zygogramma bicolorata Pallister (Coleoptera: Chrysomelidae). - Insect Sci. 17: 112-120.

PANDEY P. \& OMKaR 2013: Age based mate choice improves reproductive performance and offspring attributes in parthenium beetle, Zygogramma bicolorata Pallister. - Can. Entomol. 145: 292-301.

PARKER G.A. 1974: Courtship persistence and female-guarding as male time investment strategies. - Behaviour 48: 157-184.

PARTRIDGe L. \& BARTON N.H. 1993: Optimality, mutation and the evolution of ageing. - Nature 362: 305-311.

Perez-Staples D., Martinez-Hernandez M.G. \& Aluja M. 2010 Male age and experience increases mating success but not female fitness in the Mexican fruit fly. - Ethology 116: 778-786.

Pervez A., Omkar \& Richmond A.S. 2004: The influence of age on reproductive performance of a predatory lady bird beetle, Propylea dissecta (Mulsant). - J. Insect Sci. 4(22): 8 pp.

Pletcher S.D. \& Curstinger J.W. 1998: Mortality plateaus and the evolution of senescence: why are old-age mortality rates so low? - Evolution 52: 454-464.

PrathibHa M., Krishna M.S. \& JaYaramu S.C. 2011: Male age influence on male reproductive success in Drosophila ananassae (Diptera: Drosophilidae). — Ital. J. Zool. 78: 168-173.

Price D.K. \& Hansen T.F. 1998: How does offspring quality change with age in male Drosophila melanogaster? - Behav. Genet. 28: 395-402.
ProulX S.R., DAY T. \& Row L. 2002: Older males signal more reliably. - Proc. R. Soc. (B) 269: 2291-2299.

REAL L. 1990: Search theory and mate choice. I. Models of single-sex discrimination. - Am. Nat. 136: 376-405.

RodRiguez R.L. \& GREenfieLD M.D. 2003: Genetic variance and phenotypic plasticity in a component of female mate choice in an ultrasonic moth. - Evolution 57: 1304-1313.

Rowe L. 1994: The costs of mating and female mate choice in water striders. - Anim. Behav. 48: 1049-1056.

SRIVASTAVA S. \& OMKar 2004: Age specific mating and reproductive senescence in seven spotted ladybird, Coccinella septempunctata. - J. Appl. Entomol. 128: 452-458.

Srivastava S. \& OMKar 2005: Short and long term benefits of promiscuity in a seven-spotted ladybird, Coccinella septempunctata. - Int. J. Trop. Insect Sci. 25: 176-181.

Szcesny B., Hazra T.K., Papaconstantinou J., Mitra S. \& BolDOGH I. 2003: Age-dependent deficiency in import of mitochondrial DNA glycosylases required for repair of oxidatively damaged bases. - Proc. Natl. Acad. Sci. USA 100: 670-675.

Ueno H. 1994: Intraspecific variation of $P 2$ value in a Coccinellidae beetle, Harmonia axyridis. - J. Ethol. 12: 169-174.

Watson P.J. \& Simmons L.W. 2010: Mate choice in the dung beetle Onthophagus sagittarius: are female horns ornaments? Behav. Ecol. 21: 424-430.

Watson P.J., Arnqvist G. \& Stallmann R.R. 1998: Sexual conflict and the energetic costs of mating and mate choice in water striders. - Am. Nat. 151: 46-58.

WenNinger E.J. \& AveriLl A.L. 2006: Effects of delayed mating on reproductive output of female oriental beetle Anomala orientalis (Coleoptera: Scarabaeidae). - Agric. Forest Entomol. 8: $221-231$.

Received January 12, 2015; revised and accepted May 26, 2015 Prepublished online July 21, 2015 